\title{
A Conceptual Study on the Country of Origin Effect on Consumer Purchase Intention
}

\author{
Samin Rezvani ${ }^{1}$, Goodarz Javadian Dehkordi ${ }^{1}$, Muhammad Sabbir Rahman ${ }^{1}$, Firoozeh Fouladivanda ${ }^{1}$, Mahsa \\ Habibi $^{1} \&$ Sanaz Eghtebasi ${ }^{1}$ \\ ${ }^{1}$ Graduate School of Management, Multimedia University, Cyberjaya, Malaysia \\ Correspondence: Samin Rezvani, Graduate School of Management, Multimedia University, 63100, Cyberjaya, \\ Malaysia. Tel: 60-12-256-4481. E-mail: rezvani_samin@yahoo.com
}

\author{
Received: May 29, 2012 Accepted: June 25, 2012 Online Published: September 20, 2012 \\ doi:10.5539/ass.v8n12p205 URL: http://dx.doi.org/10.5539/ass.v8n12p205
}

\begin{abstract}
Country of origin has become a significant phenomenon in consumer behaviour studies. Hence, increasing the knowledge of customers about products makes research about factors that influence their decisions more worthwhile than before. The purpose of this paper is to review the country of origin literature and mention different variables that influence consumer purchase intention, and also highlight the relationship of variables and customer purchase intention based on the previous literature. This research is valuable for promoting the consumer behaviour literature and providing support for relationships between the variables and purchase intention. In addition, it also helps marketers who work on related topics according to the country of origin perspective. The existing literature shows that all of the variables mentioned in this paper have a relationship with customer purchase intention from the country of origin point of view. However, there are many factors for which it has not been determined whether they influence consumer purchase intention related to the country of origin issue and there is wide scope for future research and development.
\end{abstract}

Keywords: country of origin, purchase intention, country image, product knowledge, patriotism

\section{Introduction}

In just over 30 years, international trade and the development of the global market have grown considerably. Companies and international marketers are also looking for more opportunities in the global market and multinational firms, which causes international competition between companies. There are many factors that have an impact on this growth as well as consumer products and services evaluation, such as brand name and perception of country. Among the many parameters, country of origin is one of the most important affecting this competitive market. Studies show that country of origin (COO) is one of the factors that most concern marketers in respect of its impact on consumer purchase intention (L. Y. Lin \& Chen, 2006).

There are many journals concerning nationalized stereotypes, and the understanding of different nations goes back to the 1930s. Country of origin was an interesting issue for marketing examiners in the 1960s, and researchers have argued that focusing on dissimilarity and the same options for people all over the world is one of the factors of success for them. Studies show that the country of origin of products is an indicator of its quality. Country of origin is an exciting subject for marketing managers (Roth \& Diamantopoulos, 2009). The impact of country of origin on the buyer's intention dates back over three decades and purchase intention is one of the main issues considered in purchase behaviour and the international business literature (Ghazali, Othman, Yahya, \& Ibrahim, 2008).

Although there are many parameters that consumers consider when they want to buy something, such as brand, colour and design, researchers cannot ignore extrinsic factors like country of origin. The international marketing literature shows that consumers use this extrinsic factor for evaluating products. In other words country of origin is a higher risk for international trade because it reflects consumer intention. In brief, in respect of other studies and the literature, country of origin is usually abbreviated as "COO", which refers to the country that manufactures, designs or assembles a product or brand with which it is associated (J. K. Lee \& Lee, 2009).

There are various factors that have an impact on country of origin cues like product knowledge, country image and patriotism, which will be studied in this research. 


\section{Background of Country of Origin}

Nowadays, in this modern and competitive era, in which global marketing is growing day by day, country of origin, as a significant parameter, has been studied in much research, and it is shown that this factor influences consumer behaviour and also their purchasing. The other point that studies demonstrate is that people care about which country products come from and where they are made and consider these factors when evaluating the quality of products, (Parkvithee \& Miranda, 2012).

The improvement of country of origin goes back to World War 1. At that time, the defeated countries, such as Germany, were forced to put the symbol of $\mathrm{COO}$ on their product, by those that triumphed. Studies show that the aim of this act was to punish countries like Germany thereby creating a bad reputation for them (Cai, 2002).

Country of origin's influence on customer purchase intention has been a topic of study for many decades. Different cultures and histories cause dissimilar perceptions among consumers, which may lead to different evaluations about products when they want to choose. There are many parameters that have an effect on this issue, of which country of origin plays an important role in competitive markets and consumer behaviour. Stereotypes of country and the preference of customer influence the purchase intention. Political system, culture and the economy of the country can be a cause of sensitivity to people (Teo, Mohamad, \& Ramayah, 2011).

Scholars have shown that country of origin has been an extrinsic indication for evaluating products since the 1960 s, and that it is still a topic of study now. Globalization gives the chance to companies to distribute their products all over the world, and presents the opportunity for people to choose between different types of product; consequently, country of origin is a significant subject when examining consumer purchase behaviour according to foreign products. In addition, it is also a label for brands, which guides the consumers to know the firm and the country of origin (Chen, Wu, \& Chen, 2011; Michaelis, Woisetschläger, Backhaus, \& Ahlert, 2008).

Additionally, scholars believe that describing country of origin is a complex job in this global market, and they also consider that "made in" is another label for country of origin. Johansson et al. (1985) and Ozsomare and Cavusgil (1991) believe that when the headquarters of the company are gathering in one country and marketing for that brand, that location is the country of origin of that product. It is also named as the "home country" of the products. There are many researchers that also describe the country of origin (Bilkey and Nes, 1982, Cattin et al., 1982, Han and Terpstra, 1988, Lee and Schaninger, 1996, Papadopoulos, 1993 and White 1979), as the "country of manufacture or assembly". As a clear cut example, although Sony is a Japanese brand, there are some products that are assembled outside of Japan, like Singapore, so they refer to these as being "assembled in Singapore", but when they are (Sony products) assembled in Japan they are "made in "Japan.(Yasin, Noor, \& Mohamad, 2007). Country of origin is also labelled by other names like" country of manufacture", "country of assembly" and "country of design", in all issues it has a power to reviewing date about products and customer's purchase behaviour, as a result buyers think about different countries according to their awareness and beliefs, so they consider their purchase in respect of this impact (Jiménez Torres \& San Martín Gutiérrez, 2007).

\section{Purchase Intention}

Nowadays, the international trade market is very competitive and there are many new ideas on the market to attract customers. In this case, customers have many alternatives for buying products, however, there are many elements that have an effect on product success and customer purchase intention. Scholars define purchase intention as personal action tendencies according to brand. They have also concluded that intention is different from attitude. While attitude means evaluation of products, intention is the person's motivation in the sense of his or her intention to perform behaviour. Another definition declares that purchase intention is the individual's awareness to make an attempt to buy a brand (Shabbir, M. S., Kirmani, S., Iqbal, J., \& Khan, B. 2009).

Other researchers believe that purchase intention is "what we think we will buy" (Park, J. 2002). It also describes the feeling or perceived likelihood of purchasing the products that are advertised, moreover, purchase shows the level of loyalty to products. Other scholars like Daneshvary and Schower (2000) believe that purchase intention has a relationship with demographic factors like age, gender, profession and education (Lu, M. 2007). There is another statement that shows that particular features of products, perception of consumers, country of origin and perception of country of origin, all have an influence on customer purchase intention (C. L. Wang, Li, Barnes, \& Ahn, 2012). Purchase intention can also be defined as the decision to act or physiological action that shows an individual's behaviour according to the product (X. Wang \& Yang, 2008).

\section{Influence of Country of Origin on Purchase Intention and Product Evaluation}

The influence of COO on product evaluation and purchase intention has been studied since the 1960s. Many researchers who have conducted surveys on country of origin effects on consumer behaviour (Cordell in 1992, 
Brouthers and Xu in 2002, Cordell in 1992, Johansson and Ebenzahl in1986, Klein in 2002, Lee, Yun, and Lee in 2005, Nagashima in1970 and Roth and Romeoin 1992) believe that country of origin is a significant factor in influencing international marketing. The findings show that consumers evaluate goods from developing countries unfairly because of the previous beliefs of people; therefore, developing countries have a problem with this issue and face unjust evaluation. Studies have also shown that this effect differs among people similar to brand, guarantee and price, which contrasts to other tangible characteristics. In addition, buyers use country of origin as an indicator of a product's quality (J. K. Lee \& Lee, 2009). The history of the literature about country of origin goes back over 40 years, and explores whether or not the 'country of origin' of a product has an effect on consumer purchase intention (Zeugner-Roth \& Diamantopoulos, 2010). The progress of globalization means that the customer's assessment according to the country of origin is more complex than before. There is considerable literature on this issue from the 1980s, which demonstrates the clear proof of country of origin influence on consumers 'purchase intention and evaluation'. Lou and Johnson (2005) concluded that COO can be a predictor for customer thoughts and preference trend. Studies show that as an extrinsic cue, country of origin helps people in judging. This happens because evaluating extrinsic cues is more convenient than intrinsic attributes, and the important thing that should be considered is that the country of origin effect is involuntary on people's evaluation (Dagger \& Raciti, 2011);(Powers, N., \& Fetscherin, M. 2008);(Yasin, et al., 2007)

$\mathrm{COO}$ can have a positive or negative impact on customer intention, according to every effect that the country of manufacture has on the perception of the buyers. In this competitive market, companies have an opportunity to participate in the global market; therefore, the accessibility to foreign products is improved. In this situation, the role of the country of origin is more significant than before in which only domestic goods were available. In this day and age, the place of manufacture may influence people's insight in their evaluation of the quality of products. Therefore, when the number of international companies increased with globalization, more research was required about the performance of customers to lead marketers and managers in the global market. One of the most important subjects that have been studied for many years is consumer behaviour, which is capable of affecting country of origin from a different perspective. One of these perspectives is that customers basically use $\mathrm{COO}$ as an indicator among many attributes of a product for assessing the product. Another point of view is that buyers may use the "halo effect" according to country of origin for their purchase behaviour. This also plays a considerable role in customer thinking when choosing from a wide range of products. Every person has a special attitude towards his or her purchase behaviour and the parameters that influence it; even people who live in the same country with the same beliefs have different buying behaviours. As studies have demonstrated before, $\mathrm{COO}$ still affects this issue (Ghazali, et al., 2008).

Another scholar, in 1989, concluded that there are different understandings of country of origin's effect on product evaluation. First, $\mathrm{COO}$ has an impact on observations concerning specific products that can be extended to the whole product evaluation. Second, the country of origin also controls customer opinion about the country and overall goods that have been manufactured in that country; therefore, this perception may have a positive or negative effect on explanation of other data for specific product. Another point of view is that $\mathrm{COO}$ is a prominent factor that motivates concerns about the country of origin of the product, and, generally, product evaluation. Lim and Darley, in 1997, added that countries with a weak picture have a higher risk in making purchase intention (Ahmed, Johnson, Ling, Fang, \& Hui, 2002).

Scholars like Fishbein and Ajzen (1975) supposed that purchase intention could be labelled as an assessment of the act of buying, "or psychological situation which presents a special perception towards particular behaviour". Hsieh (2004) believed that the origin of customer attitude has a relation to purchase intention according to customer attitude. Lin and Chen (2006) also concluded that COO has a direct relationship with purchase intention (X. Wang \& Yang, 2008).

As a marketing tip, North American and Western European firms that compete in the global market should be aware of the domestic and foreign market according to customer perception about purchase behaviour of these products. Scholars have also conducted surveys about the judgment of products from developing countries. The scarcity of resources makes multinational companies vast and many of their operations are conducted in developing countries in Africa, Asia, Latin America and the Middle East. People get rich and the wealth of the customer in advanced developing countries has increased together with their power of purchase. This power has created the chance for Western companies whose domestic products are mature enough to trade internationally and be competitive in a foreign market (Kaynak \& Kara, 2002).

\section{Country Image}

The history of country image dates back to 1970 , when Nagashima wrote about it in an academic paper. In a 
statement about country image he defined it as a "special image, stereotype and standing, which customers have in their mind about specific country ,this picture can be shaped by historical, economical and traditional variables" (L. Y. Lin \& Chen, 2006). In addition, country image is one of the first variables that researchers test in according to foreign product and also carry on in international business and consumer behaviour studies (Kotler, 2011). Studying issues concerning country image has been prominent in international business for many years. There is considerable literature on this topic, which has caused misunderstandings among researchers about this subject (Laroche, Papadopoulos, Heslop, \& Mourali, 2005). Martin and Eroglu, in 1993, added that country of image usually refers to the "economical, political, technological and social part of each country". In addition, several researchers believe that this issue (country image) is about product characteristics. In some studies country image is representative of the country and its people, and, also, it can be shaped by experiencing the products from before. Studies show that there is considerable literature about how country of image affects the purchase intention of customers (C. L. Wang, et al., 2012). Consequently, country image in respect of customer purchase intention is one of the most significant subjects among marketers for supporting their manufactured goods. The attention to this issue is because many researchers have demonstrated that a country's image influences the prior purchase decision of customers. These kinds of investigation about country image and other related subjects dates back over three decades in developed countries (YAMOAH, 2005).

Martin and Eroglu (1993) added that the macro point of view can be defined as the overall data and explanatory beliefs gathered from a specific country. Some scholars believe that country image is because of the halo effect, especially when the manufactured goods of a country are not well-known to people, as it affects their opinions and, ultimately, the product's attributes and brand. The other point of view, which is contrary to the previous statement is that country image acts as a review construct, which means that the country of the product is memorable to customers and they are familiar with it and have experience about it. The level of involvement of products is very important in product evaluation, as a clear cut example, when people want to buy goods like wine, cosmetics, cigars or caviar, the country image and country of origin play a significant role in the purchase decision. However, it may have less effect on products with low involvement like T-shirts. By considering all the statements of researchers, it can be concluded that, the insight of people about products can be dependent on the country in which they are made. Therefore, country image has the power to affect customer belief and evaluation. It also has the power of making a weak or strong product, and, if it matches with the product, it has a positive effect, and, if not, it has a negative one; for example: BMW and Mercedes as German automobiles have a viable advantage because of the famous engineering that Germany is renowned for. In contrast, the royalty of Britain, fish and chips and the land, show that this country is not renowned for engineering in airline services and the automobile industry. Country image is not an important issue just for consumers and marketers, as it also plays an important role for global and international companies. Opinions about country image vary among different categories of products and the marketing of products is important according to the country image. When the customer assesses goods, the country of origin and positive and negative marketing also act as an important variable too (Chao, 1998). Roth and Romeo (1993) commented that Japan is a high ranked country in country image in respect of automobiles, as is Germany, which also has a high status (Srikatanyoo \& Gnoth, 2002). Researchers add that Japan is a high rating country and has a good image because of the design and high value of workmanship. They believe that the next countries with a strong ranking in image are the USA and Canada, whereas, in contrast, Korea and China are the lowest rated for country image. The matching between product category and country is another significant variable in the literature. A powerful match between country and product means that a specific country specializes in that area. Moreover, strategies to strengthen and encourage the positive aspects of each product category and country image can be an effective way. Advertising programmes can also help consumers have a good and positive image about the product's country (Dagger \& Raciti, 2011);(Pappu, Quester, \& Cooksey, 2007). There is also another point of view that considers the country image as emotional acts, which is because of certain ideas in their mind, which might also be the image from the residents of a particular country (Maher \& Carter, 2011).

Some scholars believe that country image can ease the process of purchase decision, which is related to country of origin and helps marketers in developing the strategies for global companies to improve their exports. Kim and Chung (1997) added that studies about the country image effect can be a good guide for international firms to compete in this global market. Kara (2001) included that most of the research concerns advanced countries like the USA, Japan and Western Europe, which produce high quality products and are well-known brand countries which do not provide strong marketing strategies for their product, would receive little attention (Souiden, Pons, \& Mayrand, 2011). One literature suggested that country image is an indefinable asset and that it makes a helpful contribution to marketing strategies and sales (Zeugner Roth, Diamantopoulos, \& Montesinos, 2008). 
Country image can also describe the findings and judgment for extrinsic and intrinsic cues to the rank of objects. The country image effect also concerns different types of decisions that people make like investors, buyers, customers, and which remain with the particular country. Overall, researchers concluded that country image influences the decision making process and product evaluation (Bilkey \& Nes, 1982);(Nagashima, 1970). Country image is a vital attribute in the modern and global era. Studies show that geographic areas like countries, provinces and cities can be labelled as a brand to inform people about the locations, tourists, customers and businesses (Keller, 2008).

\subsection{Country Image and Purchase Intention}

Studies about country of origin effect, have shown how country image can influence customer opinion about product quality (Bilkey \& Nes, 1982; Papadopoulos \& Heslop, 1993). Scholars have concluded that it has a direct effect on the perception about product quality (Laroche, et al., 2005). Additionally, researchers have demonstrated that product characteristics and customer information about sources of the country about manufactured goods have an effect on purchase intention. The effect of country image on purchase intention is a basic control, as a result, there is a connection between cognitive country image and purchase intention. The cognitive country image can be the technological and economic level of the country, which can influence the product image related with the workmanship and design of the country. Other researchers believe that country image has an indirect influence on purchase intention. When people are familiar with the product, they tend to use country of origin as data for intention to purchase (Chen, et al., 2011).

\section{Concept of Product Knowledge}

The literature demonstrates that product knowledge has a significant position in consumer behaviour studies (Alba, 1983; Bettman \& Park, 1980; Brucks, 1985; Cowley \& Mitchell, 2003), and, hence, is a crucial issue for other related research. A scholar defines product knowledge as the memories and knowledge's that are in people's minds(Brucks, 1985). Other researchers added that product knowledge has a relationship with consumer knowledge and recognising products and also the confidence that consumers have about it (L. Lin \& Zhen, 2005). Although there are different definitions of product knowledge it can be broken up into three main categories: 1-subjective knowledge or perceived knowledge, 2-objective knowledge, and 3-experience based knowledge. Although other scholars divide product knowledge in two portions: 1-expertise and 2-familiarity with products. Familiarity is defined as the amount of experience that a consumer has of the related products and expertise is defined as the skill in carrying out of product in a successful way, finally, the definition of experience goes to amount of products' purchase and their use. To sum up, these three definitions are used for product knowledge in the literature (Alba \& Hutchinson, 1987). Among the three definitions described above, product familiarity is the most significant one, and has dimensions of both objective and subjective knowledge. Particular characteristics of the data of the product are defined as objective knowledge and subjective knowledge is how much the customer thinks they know about products.

In 1979, a scholar found that an enormous use of new information created a high level of objective knowledge; therefore, customers with a high level of objective knowledge have a tendency to search for product information. Studies show that subjective knowledge has a greater effect on product evaluation because experience is more important than information concerning this issue, in addition, subjective knowledge is also about self judgment, and customers who are confident have less tendency to search for information relating to the product and are likely to apply stereotypical data to help them make purchase decisions. The literature revealed that customers with a high level of objective knowledge are less likely to rely on country of origin cues for their purchase intention and product evaluation and are likely to search for another trait of the product rather than country of origin. However, people with a high level of subjective knowledge have a greater tendency to rely on country of origin for evaluating the quality of a product (J. K. Lee \& Lee, 2009). One scholar believed that customer product knowledge is one of the most prominent attitudes and affects all parts of the process of making decisions, and that people with different degrees of product knowledge vary in their understanding about products. Researchers also added that customers with considerable knowledge have a better ability to compare other attributes of products and evaluate them; moreover, they are more up to date and informed. The level of knowledge has an indirect relationship with evaluation bias; if the level is high, the bias is reduced. In addition, other product knowledge, such as self-perceived knowledge, has a direct positive relationship with purchase intention (Bian \& Moutinho, 2011). Other scholars divided product knowledge into three categories: brand knowledge, attribute knowledge and experience knowledge (Hanzaee \& Khosrozadeh, 2011).

Studies show that you can measure the product knowledge in different ways, for example:

- The customer information about how much they (he or she) know the products. 
- The quantity and type of the companies that they save in their minds and memories.

- The total buying experience.

Product knowledge also plays a prominent role in information search behaviour and it is an important indicator of consumer behaviour. Usually people undertake certain actions before actually purchasing, including:

- Information search: this is a method that happens when people face several questions about consuming and they need some data about it to help them make decisions about their purchase process. This type of search is named information search.

- Information processing: this is the customer's options about agreement, accepting, selecting or retaining and it is not dependent on consumer's information; it influences the methods of information search and processing.

Researchers believe that when customers want to evaluate products, frequently, they rely on their product knowledge after choosing the product, which also influences the information search process. Moreover, the level of product knowledge is also significant, and, ultimately, has an effect on purchase intention and buying behaviour (L. Lin \& Zhen, 2005).

Josiassen and other scholars (2008) concluded that the country of origin of products has a relationship with the knowledge that the customer has about the products. They also added that consumers with little knowledge use the country of origin as an indicator for the evaluation of products more than others. The reason being that they have less information about manufactured goods (Josiassen, Lukas, \& Whitwell, 2008). Other scholars have shown that the level of technical fairness depends on the degree of familiarity of people with products. Studies show that customers with low levels of familiarity like to rely on technical fairness for purchase intention more than others (Laroche, Nepomuceno, \& Richard, 2010). Some consumers added that they have cognitive abilities and decision strategies that are different from the people who do not have knowledge or less knowledge. Customers with a high level of knowledge have a greater tendency to have more information in their memory than people with a low level of knowledge. Furthermore, they are also more conscious about particular product knowledge and product characteristics. In comparison they are less involved in product information and analysing the quality of product is very hard and complicated for them. Frey and Foppa (1986) suggested the idea about knowledge which name is personal knowledge and means "what a special things that person do and take a contemplation for her or himself". Moreover realizing the role of subjective and objective knowledge is very important for consumer scholars, especially the relationship between variables and constructs and the process of decision making (Frey \& Foppa, 1986).

Several researchers have shown that various quantify of knowledge create different prediction about customers' reactions. The content and structure of product knowledge is a significant issue in the literature. The definition of structure refers to how data are settled in the memory; in addition, the knowledge structure in the network model of memory is shown with nodes like brand and attributes. Content is about particular information concerning the class of product and special brands in the memory and also can be mentioned as a willing to choose between different products and judging about them. Overall, people with a high degree of product knowledge have vast information and an organized knowledge structure, and, also, they are aware of the product subcategories (B. K. Lee, 2005).

\subsection{Influence of Product Familiarity on the Country of Origin Image and Product Evaluation}

Previous studies show that country of origin is a complicated issue and that there are many moderators and variables that affect it. In addition, product knowledge is one of the variables that has a prominent role in respect of extrinsic cues (Chiou, 2003). The product familiarity definition explains how familiar the customer is with the product type. The relation of product familiarity and country of origin depends on the theories that scholars create according to how customers rely on the country of origin as a product evaluator for purchase decision. When researchers studied the influence of country of origin on purchase behaviour, the country of origin was defined as a halo that people were not familiar with, and used it as an indicator for product evaluation. This shows that when people have little knowledge and information about products, they use country of origin as an indirect proof, for example: people do not know a special lawn mower from Germany but they know that Germany is a country with high quality products, so although they are not familiar with the brand, they evaluate it positively. Other researchers concluded that customers use country of origin image as a cue for assessing products when they are familiar with them. In this issue, customers use country of origin as an alternative for the performance of the product while they have a perilous experience of their products in a same country of origin. For instance, a customer might have a positive experience for using a lawn mower from Germany and know the 
high standard of the products, therefore, when a new lawn mower from Germany but with a different brand is suggested to the customer, he or she will accept it because he or she believes that the quality is standard and similar to previous experience (Josiassen, et al., 2008).

Product knowledge also has an effect on advertisements; customers with different levels of knowledge for various type of products, show dissimilar reaction to advertisements. Customers who have a low level of product knowledge have more passion for advertisements that have data about the product, whereas people with a high level of knowledge and information have less passion for advertisements and responding to them (Chuang, Tsai, Cheng, \& Sun, 2009).

Studies about product knowledge and consumer behaviour have a significant position in marketing strategy. The quantity of knowledge that customers have is not only useful for information search and has an effect on it, but also has an influence on the decision making procedures, and, moreover, on customer purchase intention. Some researchers demonstrated that realizing product knowledge has a positive relationship with the amount of information search (Hanzaee \& Khosrozadeh, 2011).

The literature shows that customer product knowledge is the main topic in consumer behaviour studies. Customer product knowledge has an influence for the duration of making purchase decisions and in searching for information. One scholar added that customers make decisions after collecting and learning information, and, also, memory plays an important role in choosing products, because customers refer to their memories for purchasing behaviour and they should remember various data according to the different decision making processes. Other studies demonstrated that subjective and objective product knowledge is not unrelated, while other literature shows that consumers with high subjective knowledge do not necessarily have high objective knowledge (Yeh \& Chung, 2011). From all the data concerning product knowledge, scholars have concluded that product knowledge plays an important role in making decisions in accordance with previous memories. They also argued about the influence of product knowledge on the willingness to buy and the value of the product and the price of particular brands (Chung, S, 2008).

\section{Patriotism}

Another variable that must be considered according to country of origin is patriotism. The concept of patriotism had been demonstrated in political science literature and international business. Most of the literature presented about the topic of bias that comes with admiration of in-group and out-group. One scholar, Adorno (1950), argued about ethnocentric patriotism and healthy patriotism. Ethnocentric patriotism has been defined as when someone likes one's country with prejudice, although the healthy customer is the one with no prejudice (Adorno, Frenkel-Brunswik, Levinson, \& Sanford, 1950). Other researchers have added that patriotism includes a positive feeling besides the love of people for one's own country, and, in this case, national power and governance are not essential. The other definition for patriotism is being ready to sacrifice for the country, moreover, patriotism is not associated with a negative feeling, (Akhter, 2007). Other scholars concluded that patriotism is an emotional feeling that people have about their own country, and that it does not mean that they ignore other countries. Another scholar commented in respect of the above that patriotism is a good and positive feeling about one's nation and that it is the ability to view across the borders and fell self seemed about supra nation. In addition, it is an emotional sense about traditional customs, symbols and values about national attributes and it has a relationship with the coherent reflection of personal benefits as well as all the emotional feelings concerning one's own nation (Meier-Pesti \& Kirchler, 2003).

Some literature highlighted consumer ethnocentrism, which is another definition related to patriotism about the customers who have a tendency to buy domestic products and brands. For instance, the proportion for purchasing domestic cars by the Americans and the French is 50\% to 60\%, respectively, even though there are imported products in these countries. How can this behaviour be realized in these countries? Even though the people know that the products that are manufactured in their own country may be of a low level of quality, they think about the advantages for their own society and they close their eyes through nationalistic loyalty and believe that the products of their own country have a higher level of quality than others. This influences the global market and international production (Morse \& Shive, 2011).

\subsection{Ethnocentricity and Country of Origin}

There is considerable research about the influence of country of origin on buying decisions (Bilkey \& Nes, 1982; Peterson \& Jolibert, 1995; Samiee, Shimp, \& Sharma, 2005). Scholars believe that the influence of country of origin depends on the kind of manufactured goods, consumer perceptions, country of origin, level of patriotism depending on home country and also demographic factors. Some researchers, like Thakor and Lavack (2003), concluded that the effect of country of origin of brand is more important than country of origin of the place in 
which the product is manufactured, for example, the product may be made in Vietnam but the brand is originally from Italy, and, therefore, the country of origin plays a significant role on purchase behaviour (Thakor \& Lavack, 2003). The subjects of ethnocentrism and patriotism are discussed in any country of origin effect issue. Patriotism is also a kind of obstacle for international companies for entering the global market. This attribute arises from the preference of customers and their purchase intention towards some particular brand. Patriotism and ethnocentricity are a kind of physiological variable that influences buying foreign products. Therefore, some questions come to mind concerning what happens to domestic products versus foreign products and brands. There are many international brands on the market from various countries. For instance, the reaction of customers from developing countries is different from those from industrialized countries, when they want to choose a product, Moreover, if some brands, which are hybrid, and have some relationship with the home country, it can ease the tendency in respect of ethnocentric attitude (Shergill, Rosmala, \& Parsons, 2010). The literature shows that regardless of the developing homogeneity of the world market, patriotism and ethnocentricity are the strongest factors in the competitive global market (Vida, Dmitrovic, \& Obadia, 2008).

Ethnocentric attitude usually happens when customers want to buy foreign products and they are loyal to the brands that are manufactured in their home country, which is often the result of the country of origin effect. People with a high degree of ethnocentrism like to focus on positive parts of the domestic products and ignore the characteristics of foreign brands and have a tendency to buy local and domestic manufactured goods. The literature shows that ethnocentrism influences customer perception about the quality of foreign products and also the purchase intention. One scholar suggested that ethnocentrism can result from overestimation of the domestic products characteristics and quality or the underestimation of the attributes of foreign product. Pecotich and Rosenthal (2001) added that patriotism and ethnocentrism have a direct relationship with consumer perception about purchase intention, price and country of origin, despite the quality of products. Some findings show that for the companies whose targets are Chinese customers, the country of origin effect and other variables related to it, have limited influence on their purchase intention and evaluation (Wong, Polonsky, \& Garma, 2008).

Improving international deals and shaping the global economic and political trade attracts attention to the effect of various national origins. This subject shows the interest in the role of country of origin according to domestic and foreign products and its result on the international market and customer behaviour. Furthermore, as per the earlier discussion, it would be a barrier in the trade market to goods and services among countries. The tendency of customers for local or foreign products can depend on trust in the foreign manufacturers and brands, customer's negative feelings and ethnocentrism. Scholars found that consumer ethnocentrism is a factor that describes the preference of people about a product according to the country of origin. These kinds of studies are the result of social events and relations of groups and also human nature and conservation. Sumner (1960) defined ethnocentrism as:

"Observation in which one's group is the heart of everything, and all others are scaled and rated with reference to it. Each group nourishes its own control and looks with contempt on outsiders". This statement is good for describing customer behaviour. It is also believed that consumer ethnocentrism is a set of beliefs that people have in their mind concerning the purchase of foreign products (Ouellet, 2007). These kinds of people suppose that buying domestic manufactured goods has more advantage for their own country than buying imported ones; in addition, they mentioned that this action is immoral and unpatriotic and harms the economy of the country as well as increasing unemployment (Granzin \& Painter, 2001). Consequently, patriotism has a negative effect on consumer purchase intention and evaluation. These ethnocentrism consumers also protect the domestic market and economy and also the focus on the positive attributes of domestic products. This factor (ethnocentrism) is social and interracial (Kinra, 2006).

Waston and Wright (2000) concluded that in the case that domestic products are unreachable, customers with a high level of patriotism and ethnocentrism prefer to buy imported goods from the countries that have the same culture as their own country rather than from a country with an unrelated culture. There is also another point of view that customer patriotism results in a negative reaction to foreign advertisements and products (Yeong, Mohamad, Ramayah, \& Omar, 2007).

\section{Conclusion}

By reviewing the different literature, it can be concluded that there are many factors that have an impact on consumer purchase intention. Research and methodologies have shown that even when consumers can evaluate all the intrinsic product characteristics by experiencing the product, the effect of extrinsic cues has more influence on consumer product evaluation. Country of origin is one of the extrinsic cues; in addition, there is no doubt that country of origin has considerable influence on the purchase intention process. Subjects, such as 
product familiarity, have been the concern of foreign firms and companies that enter into global trade, since it can build consumer trust in order to achieve consumer tendency to purchase. This matter increases the return for the firm in the global market to overcome the strong competition in the global marketplace.

\section{References}

Adorno, T. W., Frenkel-Brunswik, E., Levinson, D. J., \& Sanford, R. N. (1950). The authoritarian personality.

Ahmed, Z. U., Johnson, J. P., Ling, C. P., Fang, T. W., \& Hui, A. K. (2002). Country-of-origin and brand effects on consumers' evaluations of cruise lines. International Marketing Review, 19(3), 279-302. http://dx.doi.org/10.1108/02651330210430703

Akhter, S. H. (2007). Globalization, expectations model of economic nationalism, and consumer behavior. Journal of Consumer Marketing, 24(3), 142-150. http://dx.doi.org/10.1108/07363760710746148

Alba, J. W. (1983). The effects of product knowledge on the comprehension, retention, and evaluation of product information. Advances in consumer research, 10(1), 577-580.

Alba, J. W., \& Hutchinson, J. W. (1987). Dimensions of consumer expertise. Journal of Consumer Research, 411-454. http://dx.doi.org/10.1086/209080

Bettman, J. R., \& Park, C. W. (1980). Effects of prior knowledge and experience and phase of the choice process on consumer decision processes: A protocol analysis. Journal of Consumer Research, 234-248. http://dx.doi.org/10.1086/208812

Bian, X., \& Moutinho, L. (2011). The role of brand image, product involvement, and knowledge in explaining consumer purchase behaviour of counterfeits: Direct and indirect effects. European Journal of Marketing, 45(1-2), 191-216. http://dx.doi.org/10.1108/03090561111095658

Bilkey, W. J., \& Nes, E. (1982). Country-of-origin effects on product evaluations. Journal of International Business Studies, 89-99. http://dx.doi.org/10.1057/palgrave.jibs.8490539

Brucks, M. (1985). The effects of product class knowledge on information search behavior. Journal of Consumer Research, 1-16. http://dx.doi.org/10.1086/209031

Cai, Y. (2002). Country-of-origin effects on consumers' willingness to buy foreign products: an experiment in consumer decision making.

Chao, P. (1998). Impact of country-of-origin dimensions on product quality and design quality perceptions. Journal of Business Research, 42(1), 1-6. http://dx.doi.org/10.1016/S0148-2963(97)00129-X

Chen, L. S. L., Wu, Y. J., \& Chen, W. C. (2011). Relationship between country of origin, brand experience and brand equity: The moderating effect of automobile country.

Chiou, J. (2003). The impact of country of origin on pretrial and posttrial product evaluations: The moderating effect of consumer expertise. Psychology and Marketing, 20(10), 935-954. http://dx.doi.org/10.1002/mar.10103

Chuang, S. C., Tsai, C. C., Cheng, Y. H., \& Sun, Y. C. (2009). The effect of terminologies on attitudes toward advertisements and brands: Consumer product knowledge as a moderator. Journal of Business and Psychology, 24(4), 485-491. http://dx.doi.org/10.1007/s10869-009-9122-4

Cowley, E., \& Mitchell, A. A. (2003). The moderating effect of product knowledge on the learning and organization of product information. Journal of Consumer Research, 30(3), 443-454. http://dx.doi.org/10.1086/378620

Dagger, T. S., \& Raciti, M. M. (2011). Matching consumers' country and product image perceptions: an Australian perspective. Journal of Consumer Marketing, 28(3), 200-210. http://dx.doi.org/10.1108/07363761111127626

Frey, B. S., \& Foppa, K. (1986). Human behavior: possibilities explain action. Journal of Economic Psychology, 7(2), 137-160. http://dx.doi.org/10.1016/0167-4870(86)90001-2

Ghazali, M., Othman, M. S., Yahya, A. Z., \& Ibrahim, M. S. (2008). Products and country of origin effects: The Malaysian consumers' perception. International Review of Business Research Papers, 4(2), 91-102.

Granzin, K. L., \& Painter, J. J. (2001). Motivational Influences on" Buy Domestic" Purchasing: Marketing Management Implications from a Study of Two Nations. Journal of International Marketing, 73-96. http://dx.doi.org/10.1509/jimk.9.2.73.19883

Hanzaee, K. H., \& Khosrozadeh, S. (2011). The Effect of the Country-of-Origin Image, Product Knowledge and Product Involvement on Information Search and Purchase Intention. Middle-East Journal of Scientific 
Research, 8(3), 625-636.

Jiménez Torres, N. H., \& San Martín Gutiérrez, S. (2007). The purchase of foreign products: the role of firm's country-of-origin reputation, consumer ethnocentrism, animosity and trust. Documentos de trabajo" Nuevas tendencias en dirección de empresas", (13), 1-34.

Josiassen, A., Lukas, B. A., \& Whitwell, G. J. (2008). Country-of-origin contingencies: Competing perspectives on product familiarity and product involvement. International Marketing Review, 25(4), 423-440. http://dx.doi.org/10.1108/02651330810887477

Kaynak, E., \& Kara, A. (2002). Consumer perceptions of foreign products: An analysis of product-country images and ethnocentrism. European Journal of Marketing, 36(7-8), 928-949. http://dx.doi.org/10.1108/03090560210430881

Keller, K. (2008). Strategic Brand Management. Pearson Prentice Hall: USA.

Kinra, N. (2006). The effect of country-of-origin on foreign brand names in the Indian market. Marketing Intelligence \& Planning, 24(1), 15-30. http://dx.doi.org/10.1108/02634500610641534

Kotler, P. (2011). Philip Kotler's Contributions to Marketing Theory and Practice. Review of Marketing Research: Special Issue-Marketing Legends, 8, 87-120. http://dx.doi.org/10.1108/S1548-6435(2011)0000008007

Laroche, M., Nepomuceno, M. V., \& Richard, M. O. (2010). How do involvement and product knowledge affect the relationship between intangibility and perceived risk for brands and product categories? Journal of Consumer Marketing, 27(3), 197-210. http://dx.doi.org/10.1108/07363761011038275

Laroche, M., Papadopoulos, N., Heslop, L. A., \& Mourali, M. (2005). The influence of country image structure on consumer evaluations of foreign products. International Marketing Review, 22(1), 96-115. http://dx.doi.org/10.1108/02651330510581190

Lee, B. K. (2005). The effects of product knowledge on product memory and evaluation in competitive versus non-competitive ad context: Within the item-specific and relational processing framework. The University of Texas At Austin.

Lee, J. K., \& Lee, W. N. (2009). Country-of-origin effects on consumer product evaluation and purchase intention: the role of objective versus subjective knowledge. Journal of International Consumer Marketing, 21(2), 137-151. http://dx.doi.org/10.1080/08961530802153722

Lin, L. Y., \& Chen, C. S. (2006). The influence of the country-of-origin image, product knowledge and product involvement on consumer purchase decisions: an empirical study of insurance and catering services in Taiwan. Journal of Consumer Marketing, 23(5), 248-265. http://dx.doi.org/10.1108/07363760610681655

Lin, L., \& Zhen, J. (2005). Extrinsic product performance signaling, product knowledge and customer satisfaction: an integrated analysis-an example of notebook consumer behavior in Taipei city. Fu Jen Management Review, 12(1), 65-91.

Maher, A. A., \& Carter, L. L. (2011). The affective and cognitive components of country image: Perceptions of American products in Kuwait. International Marketing Review, 28(6), 559-580. http://dx.doi.org/10.1108/02651331111181411

Meier-Pesti, K., \& Kirchler, E. (2003). Nationalism and patriotism as determinants of European identity and attitudes towards the euro. Journal of Socio-Economics, 32(6), 685-700. http://dx.doi.org/10.1016/j.socec.2003.10.006

Michaelis, M., Woisetschläger, D. M., Backhaus, C., \& Ahlert, D. (2008). The effects of country of origin and corporate reputation on initial trust: An experimental evaluation of the perception of Polish consumers. International Marketing Review, 25(4), 404-422. http://dx.doi.org/10.1108/02651330810887468

Morse, A., \& Shive, S. (2011). Patriotism in your Portfolio. Journal of Financial Markets, 14(2), 411-440. http://dx.doi.org/10.1016/j.finmar.2010.10.006

Nagashima, A. (1970). A comparison of Japanese and US attitudes toward foreign products. The Journal of Marketing, 68-74. http://dx.doi.org/10.2307/1250298

Ouellet, J. F. (2007). Consumer racism and its effects on domestic cross-ethnic product purchase: an empirical test in the United States, Canada, and France. Journal of Marketing, 71(1), 113-128. http://dx.doi.org/10.1509/jmkg.71.1.113

Papadopoulos, N. G., \& Heslop, L. (1993). Product-country images: Impact and role in international marketing. Routledge.

Pappu, R., Quester, P. G., \& Cooksey, R. W. (2007). Country image and consumer-based brand equity: 
relationships and implications for international marketing. Journal of International Business Studies, 38(5), 726-745. http://dx.doi.org/10.1057/palgrave.jibs.8400293

Parkvithee, N., \& Miranda, M. J. (2012). The interaction effect of country-of-origin, brand equity and purchase involvement on consumer purchase intentions of clothing labels. Asia Pacific Journal of Marketing and Logistics, 24(1), 7-22. http://dx.doi.org/10.1108/13555851211192678

Peterson, R. A., \& Jolibert, A. J. P. (1995). A meta-analysis of country-of-origin effects. Journal of International Business Studies, 883-900. http://dx.doi.org/10.1057/palgrave.jibs.8490824

Roth, K. P., \& Diamantopoulos, A. (2009). Advancing the country image construct. Journal of Business Research, 62(7), 726-740. http://dx.doi.org/10.1016/j.jbusres.2008.05.014

Samiee, S., Shimp, T. A., \& Sharma, S. (2005). Brand origin recognition accuracy: its antecedents and consumers' cognitive limitations. Journal of International Business Studies, 36(4), 379-397. http://dx.doi.org/10.1057/palgrave.jibs.8400145

Shergill, G. S., Rosmala, Y., \& Parsons, A. G. (2010). Young New Zealand shoppers' brand perceptions and ethnocentricity. International Journal of Retail \& Distribution Management, 38(8), 613-624. http://dx.doi.org/10.1108/09590551011057435

Souiden, N., Pons, F., \& Mayrand, M. E. (2011). Marketing high-tech products in emerging markets: the differential impacts of country image and country-of-origin's image. Journal of Product \& Brand Management, 20(5), 356-367. http://dx.doi.org/10.1108/10610421111157883

Srikatanyoo, N., \& Gnoth, J. (2002). Country image and international tertiary education. Journal of Brand Management, 10(2), 139-146. http://dx.doi.org/10.1057/palgrave.bm.2540111

Teo, P. C., Mohamad, O., \& Ramayah, T. (2011). Testing the dimensionality of Consumer Ethnocentrism Scale (CETSCALE) among a young Malaysian consumer market segment. African Journal of Business Management, 5(7), 2805-2816.

Thakor, M. V., \& Lavack, A. M. (2003). Effect of perceived brand origin associations on consumer perceptions of quality. Journal of Product \& Brand Management, 12(6), 394-407. http://dx.doi.org/10.1108/10610420310498821

Vida, I., Dmitrovic, T., \& Obadia, C. (2008). The role of ethnic affiliation in consumer ethnocentrism. European Journal of Marketing, 42(3-4), 327-343. http://dx.doi.org/10.1108/03090560810852968

Wang, C. L., Li, D., Barnes, B. R., \& Ahn, J. (2012). Country image, product image and consumer purchase intention: Evidence from an emerging economy. International Business Review. http://dx.doi.org/10.1016/j.ibusrev.2011.11.010

Wang, X., \& Yang, Z. (2008). Does country-of-origin matter in the relationship between brand personality and purchase intention in emerging economies? Evidence from China's auto industry. International Marketing Review, 25(4), 458-474. http://dx.doi.org/10.1108/02651330810887495

Wong, C. Y., Polonsky, M. J., \& Garma, R. (2008). The impact of consumer ethnocentrism and country of origin sub-components for high involvement products on young Chinese consumers' product assessments. Asia Pacific Journal of Marketing and Logistics, 20(4), 455-478. http://dx.doi.org/10.1108/13555850810909759

Yamoah, F. A. (2005). Role and Impact of Product-Country Image on Rice Marketing: A Developing Country Perspective. The Journal of American Academy of Business, 7(2), 265-276.

Yasin, N. M., Noor, M. N., \& Mohamad, O. (2007). Does image of country-of-origin matter to brand equity? Journal of Product \& Brand Management, 16(1), 38-48. http://dx.doi.org/10.1108/10610420710731142

Yeh, R. C., \& Chung, P. (2011). Study of Product Brand Image and Individual's Product knowledge and Perceived Risk Affecting on Consumer Purchasing Behavior.

Yeong, N. C., Mohamad, O., Ramayah, T., \& Omar, A. (2007). Purchase preference of selected Malaysian motorcycle buyers: the discriminating role of perception of country of origin of brand and ethnocentrism. Asian Academy of Management Journal, 12(1), 1-22.

Zeugner Roth, K. P., Diamantopoulos, A., \& Montesinos, M. Á. (2008). Home country image, country brand equity and consumers' product preferences: an empirical study. Management International Review, 48(5), 577-602. http://dx.doi.org/10.1007/s11575-008-0031-y

Zeugner-Roth, K. P., \& Diamantopoulos, A. (2010). Advancing the country image construct: Reply to Samiee's (2009) commentary. Journal of Business Research, 63(4), 446-449. http://dx.doi.org/10.1016/j.jbusres.2009.09.009 